$$
\begin{array}{r}
\text { 低改良率セメントコラム工法 }(\mathrm{ALiCC} \text { 工法）の施工事例について† } \\
\text { 近藤 益央* 宮武 裕昭* } \text { 大林 淳** }^{* *} \text { 新川 直利** 柳浦良行*** }
\end{array}
$$

\title{
Construction Cases of Arch Action Low Improvement Ratio Cement Column Method
}

by

\author{
Masuo KONDOH *, Hiroaki MIYATAKE *, Jun OHBAYASHI **, \\ Naotoshi SHINKAWA ** and Yoshiyuki YAGIURA ***
}

\begin{abstract}
A soil improvement of the low improved rate is effective for cost reduction of countermeasure for soft ground and shortening the construction period. Therefore we developed a new design method that could consider an arch action to occur in embankment. It is possible to evaluate embankment load carrying cement column and non-improved soft ground by the arch action. Therefore it is possible to distribute improved cement column distance bigger than a conventional construction method. It is complete and places an improved cement column under the embankment. So, it is possible to control settlement and differential settlement of the embankment, moreover it is becoming cost reduction of countermeasure for soft ground and shortening the construction period. In this report, we introduce the outline of the Arch Action Low Improvement Ratio Cement Column Method, and we clarify the effectiveness by comparing ALiCC method and conventional methods.
\end{abstract}

\section{Key words:}

Low improvement ratio, Arch action, Low construction fee, Shorten construction period

\section{1 緒言}

軟弱地盤対策の工費および工期の縮減策として，地盤 改良の低改良率化は極めて有効な手段であり，低改良率 セメントコラム工法 (以下,「ALiCC 工法」と呼ぶ) はそ の 1 つとして現場に適用される事例も増えている.

ALiCC 工法では, 盛土内に発生するアーチ効果を考慮す ることでセメント系改良体と未改良地盤に作用する盛土 荷重を合理的に評価し，塑性角 $\theta$ をパラメータとした簡 便な設計法 1)で従来工法よりも大きな間隔で改良体を設 計配置することが可能となった，その結果，盛土直下の 改良体を全面的に均等配置することにより, 盛土の沈下 量, 不同沈下を抑制しつつも, コス卜縮減や工期短縮も 図ることができる，さらに，平面的な低改良率化のみな らず, 従来工法として採用されていた着底型のほかに, 改良体を着底させない浮き型（フローティング型）によ り, 改良体積を少なくすることも可能とした。 また，軟 弱地盤対策が施される地盤環境, 盛土条件等は様々であ ることから，ALiCC 工法の実施事例においても補助工法 を併用するなどの様々な工夫が取り入れられている. 本 報告では，ALiCC 工法の概要を紹介寸るとともに，これ までの実施事例の中から特徵的な施工実績を報告し, 他 工法との比較を行うことにより本工法の有効性について 報告するものである.

\section{$2 \quad$ ALICC 工法の概要}

軟弱地盤対策 2)において, セメントなどの改良材を用い た地盤改良の果た寸役割が大きくなり, 地盤改良のコス 卜縮減, 工期短縮のニーズが高まった。 土木研究所では 平成 10 年度〜 14 年度に基礎地盤コンサルタンツ㑣, 怢キ タック，侏不動テトラとともに共同研究に取組み, 従来 よりも面的に低い改良率（改良する面積率が 10\% 30\% 程度）で地盤改良を行い，盛土の安定や沈下抑制を図る 「低改良率セメントコラム (ALiCC) 工法」を開発した。

従来から用いられている深層混合処理工法による軟弱 地盤対策 2)-5)は, Fig. 1 に示寸ように盛土の両サイドのの り面下を集中的に改良する形式（改良率 $50 \%$ 以上）が主 体であった，これは「盛土の安定を図る上でもっとも効 果的なのは，のり面下の改良である」という円弧すべり 安定計算からの結果に基づくものであった，そのため, のり面下は深層混合処理工法による地盤改良を施し, 盛 土中央部下の軟弱地盤に対してはサンドドレーンやペー パードレーン等の圧密促進工法 (以下,「従来工法」と呼 ぶ）が施していた。この組合せは盛土周辺への側方変形 の抑制といら観点からも, 長い間この改良形式による対 策が主流となっていた。しかしながら，改良の行われて いない盛土下中央で大きな圧密沈下が生じ，これにより

$\dagger \quad$ 原稿受理 平成27年5月22日 Received May 22, 2015 (C2016 The Society of Materials Science, Japan

* (国研)土木研究所 地質・地盤研究グループ施工技術チーム Geology and Geotechnical Engineering Research Group, Public Works Research Institute, Minamihara, Tsukuba 305-8516.

** (株)不動テトラ 地盤事業本部 †103-0016 東京都中央区日本橋 Geo-Technical Division, Fudo Tetra Co., Chiou-ku, Tokyo 103-0016

***基礎地盤コンサルタンツ(株) 事業本部 テ136-8577 東京都江東区亀戸 Engineering Department, Kiso-Jiban Consultants Co., LTD., Koto-ku, Tokyo 136-8577 


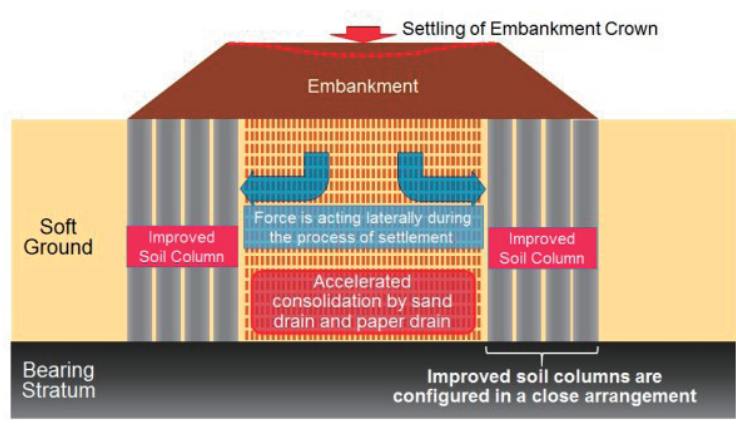

Fig. 1 Conventional Method.

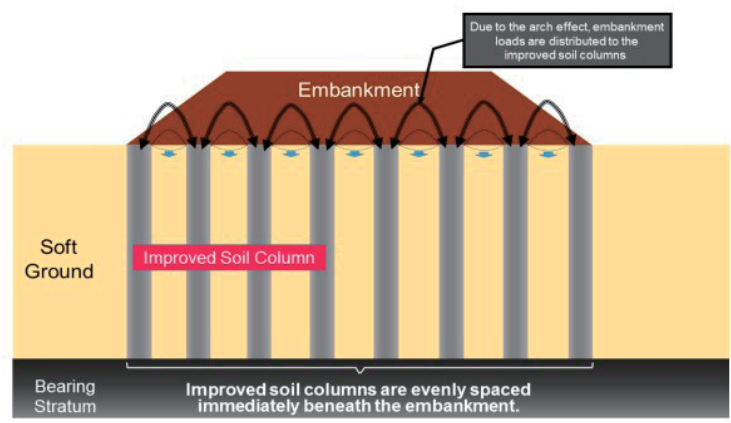

Fig. 2 ALiCC Method

のり面下の改良柱体が外側に押され，盛土周辺部に側方 変形が発生したり，地盤改良部と圧密促進部とで不同沈 下による段差が発生し，盛土内にき裂が生じるなどの問 題も起きることもあった。これらは不均等な改良体配置 の影響と考えられる.

ALiCC 工法は，セメント系改良体と未改良地盤に作用 する盛土荷重を合理的に評価することができる設計法で ある。アーチ部に発生する塑性角を盛土材料や併用する 補助工法別に定め，この塑性角を用いてセメント系改良 体と未改良地盤に作用する盛土荷重を算出する。軟弱地 盤の圧密沈下軽減，盛土の安定確保を図るために，Fig. 2 に示すとおり，深層混合処理等により盛土下に全面的に くまなく, 従来の深層混合処理工法に比べ低い改良率 (改 良対象区域全体の面積に対する，改良柱体の杭頭部分の 面積の割合）となるよう，セメント系の改良柱体を造成 することを特徴とする工法であり，改良率 10～30\%を想 定している．改良方式には，Fig. 3 に示すように盛土完成 後から供用までの期間が短く，沈下量を抑制したい場合 に適している，改良柱体を支持基盤に着底する「着底型」 と，着底型に比べて沈下量は多くなるが，供用までに十 分な期間がある場合や地盤改良コストを抑制したい場合 に適している，改良柱体を支持基盤に着底させない「浮 き型」の 2 つのタイプがある. Fig. 4 に示すように「浮き 型」は盛土完成後も沈下が継続するが，改良体積を低く 抑えることで施工コストや施工日数を抑えることができ る。 ALiCC 工法は盛土内に発生するアーチ効果を考慮す ることでセメント系改良体と未改良地盤に作用する盛土 荷重を合理的に評価することで，従来工法よりも大きな 間隔とすることができる設計法であり，改良体構築につ いては従来から用いられている HL-DJM 工法等の機械擋

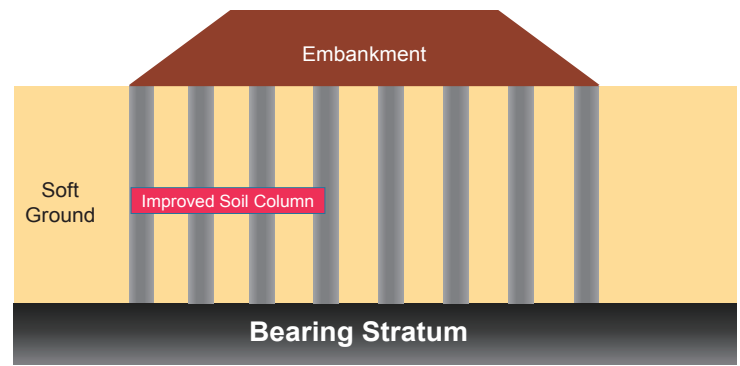

(a) Fixed Type

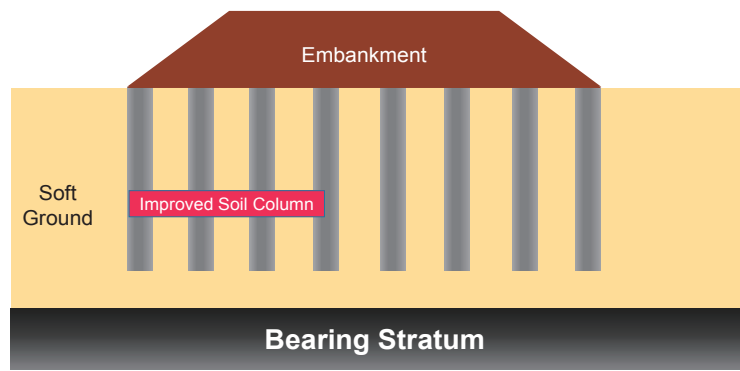

(b) Floating Type

Fig. 3 Improved Type for ALiCC Method.

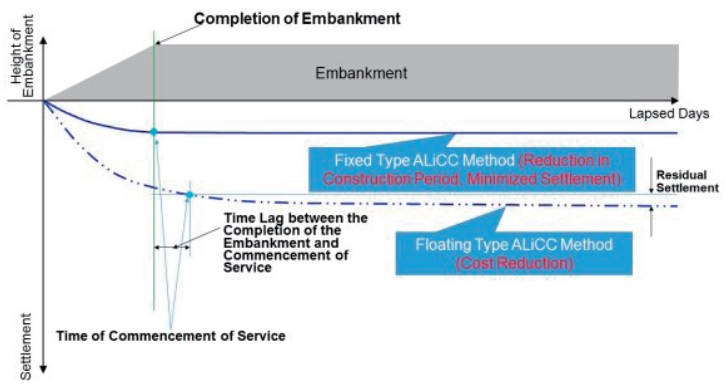

Fig. 4 Conceptual Drawing of Settlement.

$14.0 \mathrm{~m}$

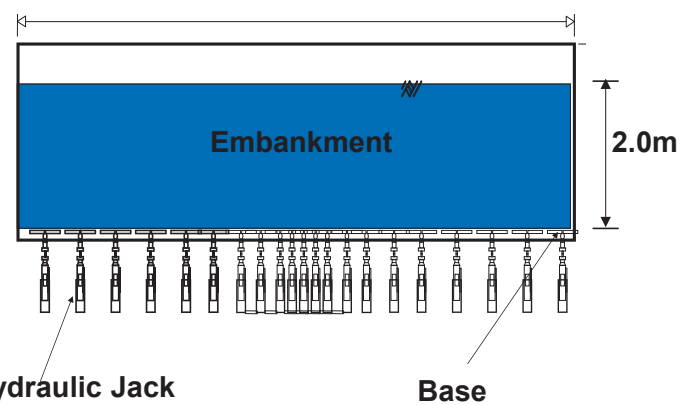

Fig. 5 Settlement Model Test.

拌式深層混合処理工法を用いることで, 特殊な施工機械 を必要としないことも特徴の一つである.

Fig. 5 に盛土内に発生するアーチ効果を検証するため の実験模型 6)を示す.土槽下部に設置した油圧ジャッキに は底版を取り付け，この底版には土圧計を設置した。油 圧ジャッキは改良体および未改良地盤を模擬しており， 未改良地盤を模擬したジャッキを下げることで, 未改良 地盤の圧密沈下を再現した。その際に改良体に作用する 応力と未改良地盤に作用寸る応力を測定することで，盛 土内に発生しているアーチ効果を確認した. Fig. 6 に油圧 ジャッキによる不同沈下の再現状況を示す. 改良体径を $1.0 \mathrm{~m}$ とし, 改良体間隔を $0.3 \sim 1.8 \mathrm{~m}$ を変化させ，改良率 


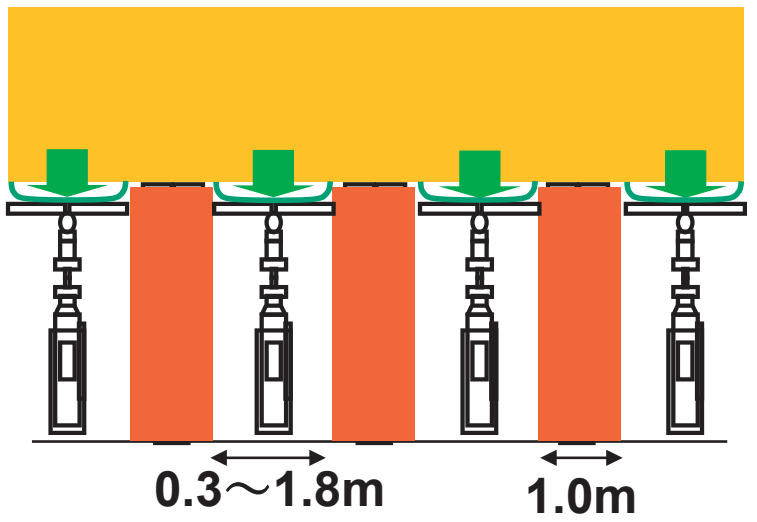

Fig. 6 Ground Subsidence by Hydraulic Jack.

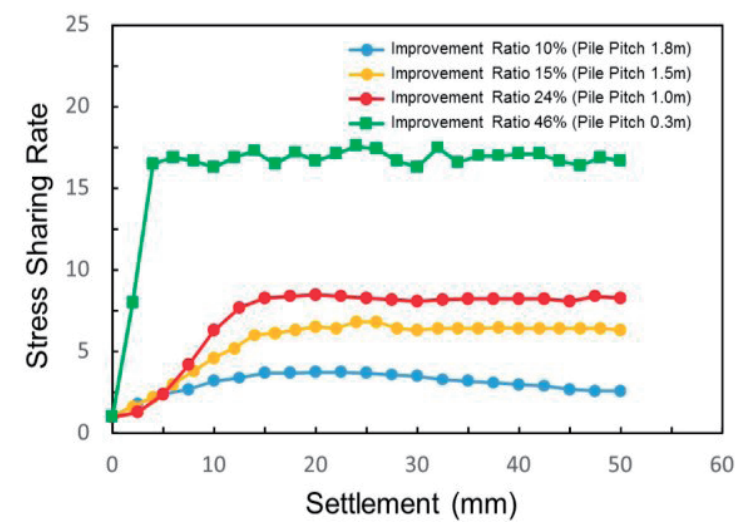

Fig. 7 Drawing of Settlement.

Table 1 Plastic Angle $\theta$ for ALiCC Method.

\begin{tabular}{|c|c|c|c|}
\hline & $\begin{array}{c}\text { Without } \\
\text { Combination }\end{array}$ & $\begin{array}{c}\text { Combination of } \\
\text { Shallow Soil } \\
\text { Treatment }\end{array}$ & $\begin{array}{c}\text { Combination of } \\
\text { Geotextile }\end{array}$ \\
\hline Fixed Type & $90-\boldsymbol{\phi}$ & 75 & 55 \\
\hline Floating Type & 80 & 85 & 75 \\
\hline
\end{tabular}

$\Phi$ : Shear Resistance Angle

の違いによる改良体に作用する応力と未改良地盤に作用 する応力の比を求めた. 応力分担比と盛土沈下量の関係 に関する実験結果を Fig. 7 に示す. 同図の応力分担比が 1.0 の場合，改良体部でも未改良地盤部でも同じように盛 土荷重を分担していることになり，応力分担比が大きい ほど，未改良地盤部に作用する盛土荷重が少ないことを 表している，同図から改良体間隔を広げると応力分担比 が下がることがわかる，改良率換算で $15 \%$ になる改良体 間隔 $1.5 \mathrm{~m}$ の実験結果では沈下量を増加させても応力分担 比が減少することはなかったが，改良率換算で $10 \%$ にな る改良体間隔 $1.8 \mathrm{~m}$ の実験結果では沈下量が増加すると 徐々に応力分担比が下がることがわかる．これは，盛土 内で発生するアーチ効果が維持できず，未改良地盤部の 沈下が増加するにつれて未改良地盤部に作用する盛土荷 重が増加していることを表す。従ってアーチ効果を考慮 した低改良率化においても 10～30\%程度にすることが望 ましいことがわかった7).

ALiCC 工法では改良域全体を複合地盤として取り扱い, 着底型の場合には全沈下量 $S$ を式(1)で求め, 許容残留沈 下量と比較する.
$S=\frac{P}{E_{e q}} L$

ここに，P:盛土により改良領域に作用する応力,

$L$ : 改良体長さ $(\mathrm{m}), E_{\text {eq }}$ : 複合地盤の変形係数で次式よ り算出.

$E_{e q}=a_{p} \times E c o l+\left(1-a_{p}\right) E_{\text {soil }}$

ここに, $a_{p}$ : 改良率, $E_{c o l}$ : 改良体変形係数で配合試験 結果から決定, $E_{\text {soil }}$ : 改良体間の無処理地盤の変形係数で, 地盤調査結果から決定.

Table 1 に示す塑性角 $\theta$ を用いることで簡便な方法で不 同沈下量 $\delta_{s}$ を算出できるものとした.

$\delta_{s}=S_{\text {soil }}-S_{\text {col }}$

ここに， $S_{\text {soil }}$ : 改良体間の無処理地盤の沈下量で式(4) から算出, $S_{c o l}$ : 改良体の沈下量で式(5)から算出

$$
\begin{gathered}
S_{\text {soil }}=S_{0} \frac{P_{\text {soil }}}{P} \\
\text { ここに, } \quad S_{0}=\frac{C_{c}}{1+e_{0}} H \log \left(\frac{\sigma_{v}{ }^{\prime}+P}{\sigma_{v}{ }^{\prime}}\right) \\
P_{\text {soil }}=\frac{V_{\text {soil }}-\gamma}{\lambda^{2}-\pi d^{2} / 4} \\
V_{\text {soil }}=\left\{\frac{\lambda(\lambda-d)}{2}-\frac{\pi\left(\lambda^{3}-d^{3}\right)}{24}+\frac{(4-\pi)(\sqrt{2}-1)}{24} \lambda^{3}\right\} \tan \theta
\end{gathered}
$$

$C_{c}$ : 圧縮指数, $e_{0}$ : 間隙比, $\sigma_{v}{ }^{\prime}$ : 平均有效鉛直応,

$H$ : 盛土高さ $(\mathrm{m}), P_{\text {soil }}$ : 改良体に作用する盛土応力,

$V_{\text {soil }}$ : 改良体に作用する盛土体積 $\left(\mathrm{m}^{3}\right)$,

$\lambda$ : 改良体軸間距離 $(\mathrm{m}), \gamma$ : 盛土の単位体積重量 $\left(\mathrm{kN} / \mathrm{m}^{3}\right)$, $d$ : 改良体径 $(\mathrm{m}), \theta$ : 塑性角で Table 1 の值を用いる

$$
\begin{aligned}
& S_{c o l}=\frac{P_{c o l}}{E_{c o l}} L \\
& \text { ここに } \quad P_{c o l}=\frac{V_{\text {soil }} \times \gamma}{\lambda^{2}-\pi d^{2} / 4}
\end{aligned}
$$

すべりに対する安定性や改良体の鉛直応力に対する照 査は, 従来の深層混合処理工法における照査方法と同様 である. 塑性角 $\theta$ を用いることで, 簡便に改良体と未改 良地盤とで発生する不同沈下量を算出できるのが特徴で ある ${ }^{8)}$ 。

\section{ALiCC工法の施工事例}

本工法は低改良率での沈下低減効果を主な目的として 数多くの現場で採用されてきた。他の地盤改良工法とコ ストや工期を比較して採用される事例が多い. 以下に, 主だった施工事例を紹介する.

\section{1 着底型の施工事例}

着底型は盛土荷重を改良体から基盤に伝える形式であ るため，盛土施工後の不同沈下を抑制することができる. そのため，圧密沈下時間を考慮する必要がないことから 工事期間を短縮することが可能な工法である.

着底型の施工事例として県道石岡つくば線バイパスで の施工事例(Fig.8 参照)を紹介する. 本工事は茨城県が事 業主体として茨城県石岡市の県道 138 号石岡つくば線バ イパス（以下「石岡つくば線」という）の府中橋から国 道 355 号までの約 $380 \mathrm{~m}$ の区間で, 非常に軟弱な地盤上に 


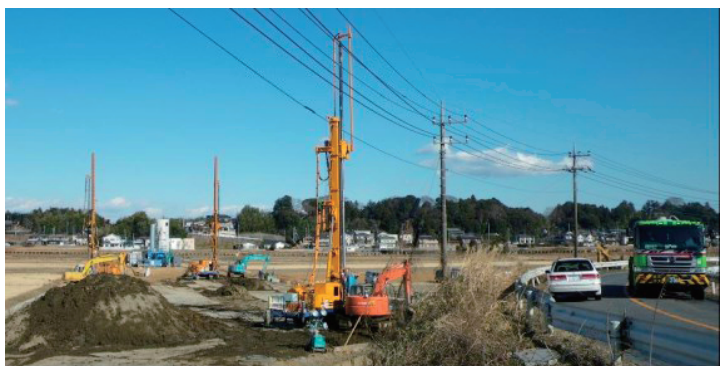

(a) Construction State of Improved Soil Column

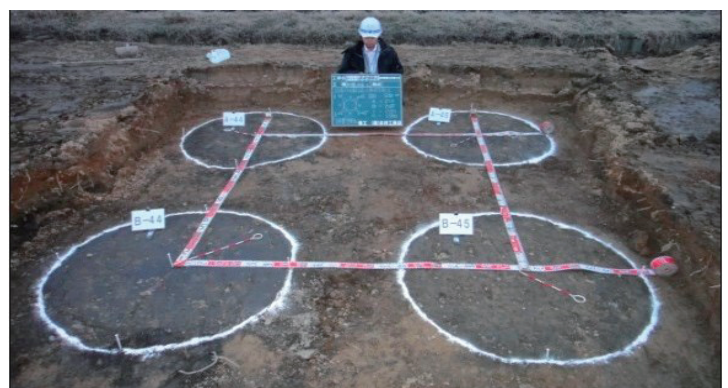

(b) Layout Situation of Improved Soil Column Fig. 8 Construction Situation.

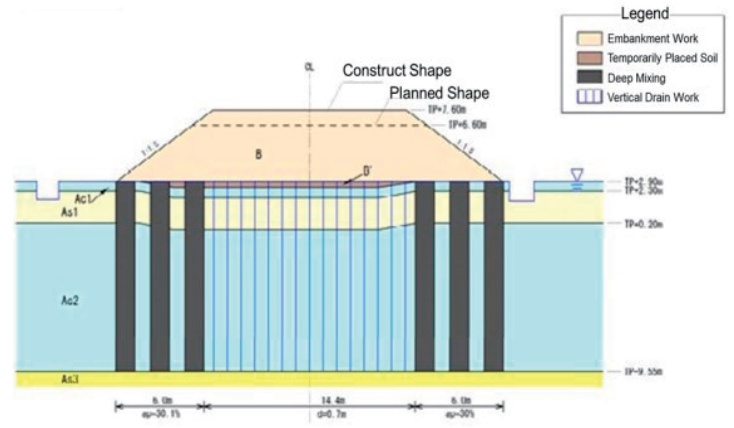

(a) Trial Design by the conventional method

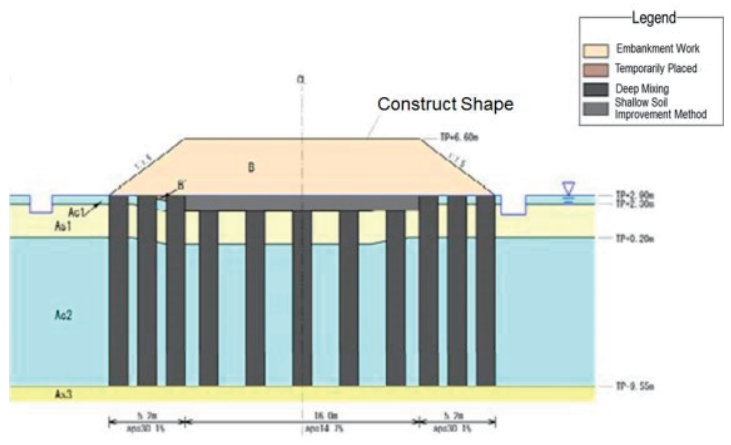

(b) Trial Design by the ALiCC method Fig. 9 Trial Design

建設されることから，盛土による沈下や周辺変位の発生 が懸念されていた。しかし，慢性的な渋滞の解消のため 早期供用が求められ，沈下低減効果・工期短縮が可能な ALiCC 工法が採用されることとなった。また，ALiCC工 法では様々な改良機を使用することが可能であり，石岡 つくば線では施工中の地盤変位を抑制し周辺構造物への 影響が懸念されたことから，低変位施工が可能な超小型 CI-CMC 改良機が採用されている. CI-CMC 改良機は低変 位施工のみならず，架線などの上空制限がある工区でも 採用可能な改良機であることから，ALiCC 工法は様々な 現場環境に対応可能な工法であるといえる.

Fig. 9(a)に示した従来工法と、Fig. 9(b)に示した ALiCC 工法の比較を経済性、信頼性、工期、実績等で評価した。

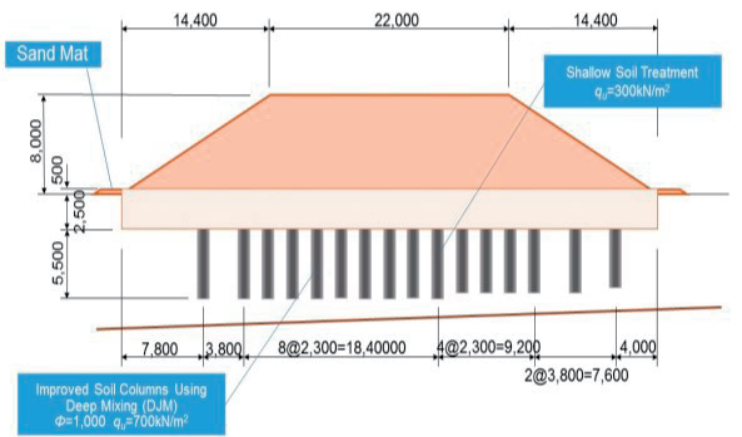

Fig. 10 Standard Lateral Profile.
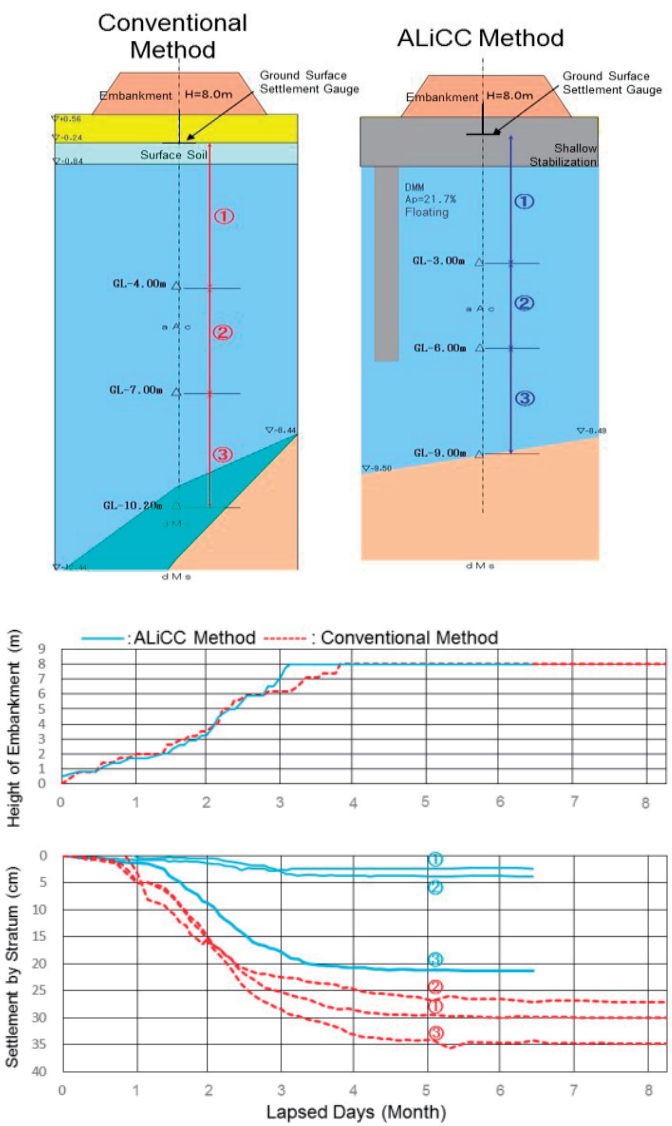

Fig. 11 Settlement Comparison with Conventional Method.

Fig. 9(b)に示したように ALiCC 工法に浅層改良を併用し ていることも有り, ALiCC 工法の工費は従来工法と比較 して約 5\%割高になったが，ドレーン工による圧密期間を 見込まなくても良いため工期が短縮できること, 圧密沈 下の抑制効果が従来工法に比べて高いことから, 総合的 に評価が優位となったことから，ALiCC 工法が採用され た

\section{2 浮き型（フローティング型）の施工事例}

浮き型は改良体長を軟弱地盤層厚より短くし，改良体 体積を減らすことでコスト縮減を図りたい場合，周辺部 と協調的な沈下性状を得たい場合, 低改良率で応力の集 中を緩和したい場合に適している。改良体が基盤に着底 していないので，盛土完成後も沈下が継続する。このた め，盛土完成から供用開始まで時間的余裕が必要となる が，一層の経済化を図ることが可能である.

浮き型の施工事例として国道 208 号有明海沿岸道路 (以 下「有明海沿岸道路」という）での施工事例(Fig.10 参照) 
を紹介する。本工事は国土交通省福岡国道事務所が事業 主体として福岡県大牟田市の国道 208 号有明海沿岸道路 の昭和開地区において試験施工として施工されたが，そ のまま本線として使用されている。試験盛土区間では, 様々な地盤改良工法が施工されており, 従来工法も施工 された. Fig. 11 に示したように, 約 $9 \mathrm{~m}$ の軟弱地盤に対し て深度約 $6 \mathrm{~m}$ まで深層混合処理による改良体を構築し, 地 表面から $2.5 \mathrm{~m}$ まで浅層改良を施した後, $8 \mathrm{~m}$ の盛土を構 築した. Fig. 11 に示したように, 浮き型 ALiCC 工法の沈 下量（層別沈下量の和）は盛土完成後も沈下が継続する ものの，盛土完成後約 2 ケ月で沈下は収束している。こ れに対して，従来工法の場合には盛土完成後約 3 ヶ月で 沈下が収束しており，浮き型 ALiCC 工法の沈下収束が従 来工法と比較して若干早かった。地表面位置での沈下量 は，ALiCC 工法は従来工法の $1 / 2$ 以下であった。層別 沈下量で夕ると ALiCC 工法の場合には，未改良部での沈 下量がほとんどを占めていることがわかる.

また，施工開始前から法尻地表面で生じた水平変位を 比較すると, 従来工法の場合には $21 \sim 35 \mathrm{~cm}$ の変位が生じ たのに対して ALiCC 工法では $2 \mathrm{~cm}$ 以下の変形に収まり, 非常に高い変形抑制効果が認められた。ささらに，盛土天 端における不同沈下は非常に小さく, 浅層混合処理工法 と ALiCC 工法を組合せた工法は, 従来工法と比較して, 不同沈下の抑制や周辺地盤の変形抑制に非常に高い効果 を発揮する事が確認された.

3.3 かさ上げ堤防・腹付け盛土への施工事例

新規に盛土や堤防を施工する場合には盛土や堤防直下 を全面的に地盘改良する工法が一般的であるが，かさ上 げ堤防や腹付け盛土の場合には，既存の盛土等があるた め部分的に地盤改良を施すことになる。このような変則 的な地盤改良として ALiCC 工法が採用された事例として, 円山川一日市地区軟弱地盤対策工事での施工事例(Fig.12 参照)を紹介寸る。本工事は国土交通省豊岡河川国道事務 所が事業主体として兵庫県豊岡市一日市・宮島・小田井 地先（以下「一日市地区」という）において施工された。 円山川では，平成 16 年 10 月の台風 23 号による被害をう け，再度の災害を防止するため河川激甚災害対策特別緊 急事業が採択され，河道掘削，築堤，内水対策，堤防強 化等が実施された。堤防の腹付け盛土が行われた一日市 地区の地盤特性は下記のとおりである。

(1)軟弱な沖積層（As 層，Ac 層）が 30m〜 40m堆積して いる。下流部ほど沖積層が厚い。その下位には洪積層と 考えられる砂碩層 (Dg 層) が分布する.

(2)沖積層は，上部に緩い砂質土層（As 層)，その下位に は $\mathrm{N}$ 值が 1～5の粘性土層（Ac2 層）となっており，その 厚さは 35m〜25mほどに達している。 円山川で築堤を実 施した場合，当該層が著しい圧密沈下をおこすことが予 想される.

(3)粘土層 Ac2 層は, $35 \mathrm{~m} \sim 25 \mathrm{~m}$ ほどの層厚であるが,

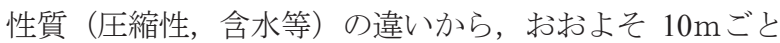
に3つに分けられる（Ac2-1，2-2，2-3）.

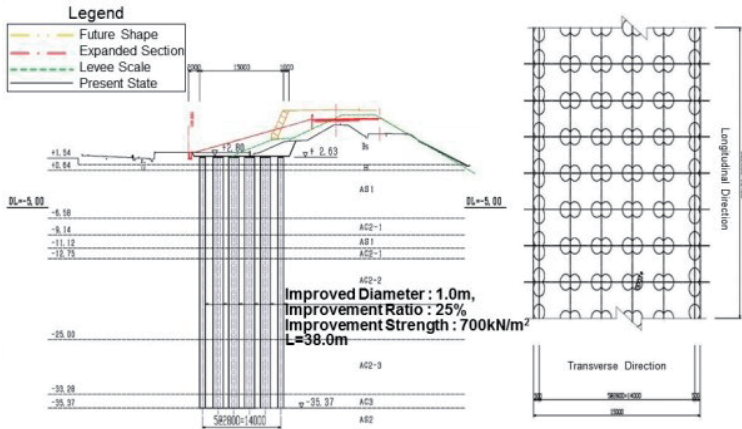

Fig. 12 Standard Lateral Profile.

Widening of Embankment for Restoration Embankment of the Original Condition

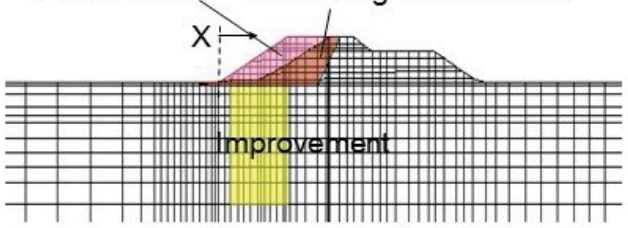

$\varepsilon$

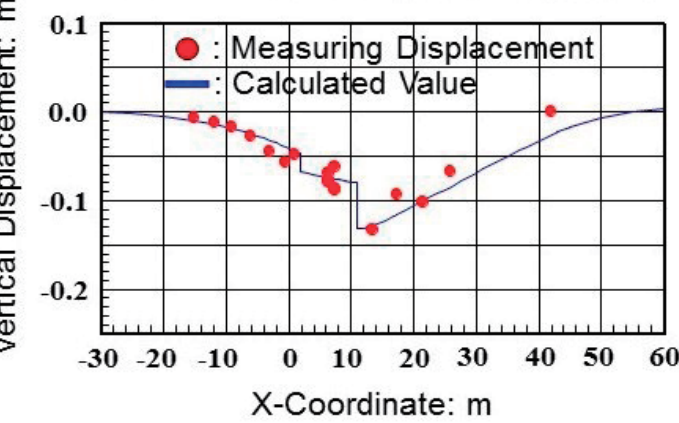

(a) ALiCC Method

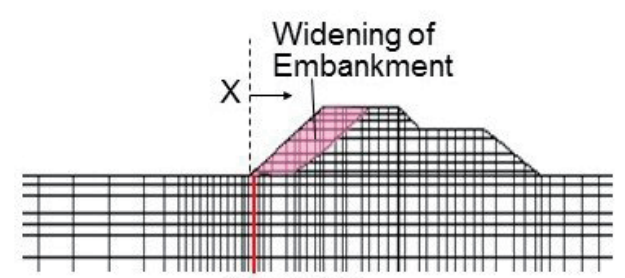

Sheet Pile

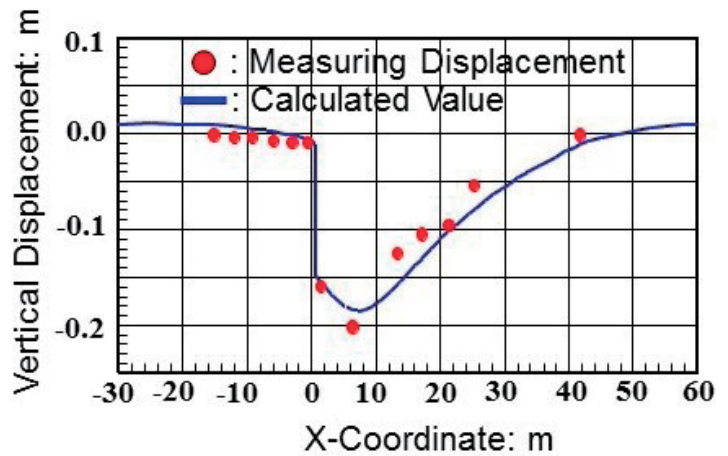

(b) PFS Method

Fig. 13 Settlement Comparison with Conventional Method.

(4)沖積層の下部には砂礫を主体とした洪積砂礫層が分 布している。この砂磎層の $\mathrm{N}$ 值は概ね 50 以上と高く, 豊 岡盆地においては多くの構造物支持層となっている.

一日市地区では，腹付け盛土による地盤の変形によっ て，周辺家屋に被害を与えないことが重要な選定条件と なっていた。 そこで，一日市地区における対策工法とし 
て、ALiCC 工法と部分フローティング式鋼矢板工法（以 下「PFS 工法」という）の 2 工法に絞り込まれ，解析的検 討と併せて試験施工も施された. PFS 工法は, フローティ ング鋼矢板と着底(支持)鋼矢板を交互に打設することで 応力遮断壁を構築し, 盛土側の沈下の影響を縁切りする 工法である. PFS 工法では, 盛土側の沈下により発生する 応力が堤内側に伝わらなくなるため, 周辺地盤の沈下を 抑制することが出来る.ただし，地盤状況によっては水 平変位に対しては効果が期待できないことがある．従来 の矢板工法と比べ，支持層まで打設する鋼矢板が減るこ とから，特に支持層の深い場合には施工性，経済性に優 れた工法である. Fig. 13 に示したように, 法尻を $0 \mathrm{~m}$ (X 座標）とした場合，堤内地（X座標のマイナス側）での 鉛直変位では PFS 工法が ALiCC 工法に対して影響範囲が 小さくなっている. しかし, 盛土側での沈下量に着目す ると, ALiCC 工法の方が PFS 工法と比べて沈下抑制効果 が大きいことがわかった. PFS 工法, ALiCC 工法ともに 周辺地盤への影響，沈下量が適用条件以内であったが， 多くの検討対象地域で ALiCC 工法の方が経済的に優位で あったことから，ALiCC工法が選択された。

\section{4 結言}

ALiCC 工法は盛土直下を低改良率で地盤改良すること で不同沈下を押さえつつコスト縮減を目指寸工法 9) 11)で ある，本報告に示したように，現場条件に合わせて着底 型や浮き型を選択できるほか, 浅層改良やジオテキスタ イルとの併用も可能な技術である。また，地盤改良を施 す際の改良機械も従来から活用され，使用実績の多い機 械撹汼方式を用いていることから，機材の調達も比較的 容易である。

Fig. 14 に示すように施工実績を伸ばしており，平成 26 年 12 月末現在では累積施工件数 104 件, 累積施工土量は 87 万 $\mathrm{m}^{3}$ を超えている. 平成 20 年 3 月には ALiCC 工法研 究会を設立し, 工法の普及, 設計および施工技術の向上 を図っているところである，さらに，平成 27 年 4 月には マニュアルを改訂 ${ }^{1)} し$, 適用範囲を明確にするとともに, 設計計算例を充実させた.

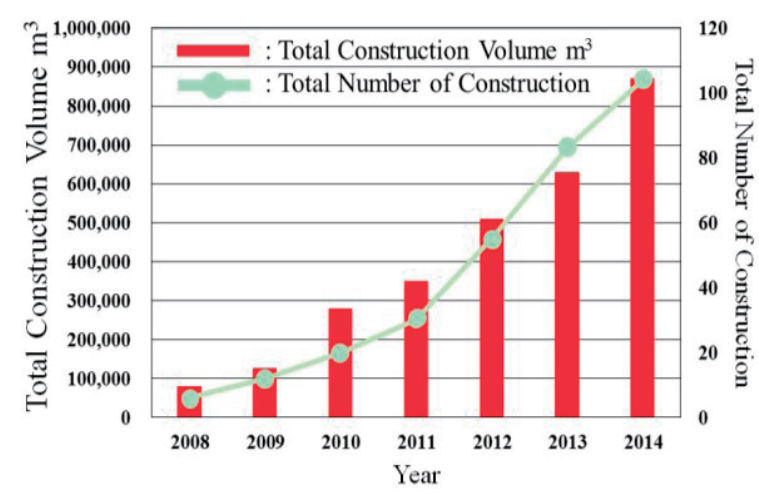

Fig. 14 Achievements of ALiCC Method.

NETIS の事後評価を受けたこともあり，今後さらに軟 弱地盤対策を必要とする現場で本工法が採用され, 建設 工事の効率化につながることを期待するものである.

\section{参 考 文 献}

1) ALiCC Method Association, "ALiCC Method Manual for the Ground Improvement”, (2015) Kajima Institute Publishing Co., Ltd.

2) Japan Road Association, "Road Earthwork Guideline for Mitigating Measures for Soft Ground Improvement", (2013) Japan Road Association

3) Public Works Research Center, "Design and Construction Manual for Deep Mixing of Earthworks", (2004) Public Works Research Center

4) Cement Deep Mixing Method Association, "CDM Q\&A Collection", (2005) Cement Deep Mixing Method Association

5) DJM Method Association, "Dry Jet Mixing (DJM) Method Technical Manual", (2006) DJM Method Association

6) H. Tsuyuki, M. Sawada, T. Nishiguchi and H. Fujimra, "Application of Arch Action Low Improvement Ratio Cement Column Method to Inclined Ground", Proceedings of 10th National Symposium on Ground Improvement, CD-ROM, (2010) The Society of Materials Science

7) M. Kondoh, H. Miyatake and S. Miyagawa, "Research on the Arch Action Low Improvement Ratio Cement Column Method Constructed on Inclined Ground", Proceedings of the 69th Annual Conference of The Japan Society of Civil Engineers, CD-ROM, (2014) Japan Society of Civil Engineers

8) S. Tsutsumi, H. Kohashi, S. Sakajou and M. Yabu, "Development of Economical Raising Method for Embankment on Soft Ground", Proceedings of the 47th Japan National Conference on Geotechnical Engineering, CD-ROM, (2012), The Japanese Geotechnical Society

9) S. Tsutsumi and H. Kohashi, "Research Development of Deep Mixing Method", CD-ROM, (2012), Proceedings of International Conference on Ground Improvement and Ground Control (ICGI 2012)

10) M. Kondoh, H. Miyatake, S. Miyagawa, J. Ohbayashi, N. Shinkawa, Y. Yagiura and H. Morita, "Introduction of Arch Action Low Improvement Ratio Cement Column”, Proceedings of the 11th Symposium on Ground Improvement, CD-ROM, (2014), The Society of Materials Science

11) M. Kondoh, H. Miyatake, J. Ohbayashi, N. Shinkawa and Y. Yagiura, "Case Histories of Arch Action Low Improvement Cement Column Method (ALiCC Method)", Proceedings of 2015 Deep Mixing Conference, pp.1005-1014, (2015), Deep Foundations Institute 